\title{
III. ДИСКУССИИ
}

https://doi.org/10.21638/2226-5260-2019-8-1-328-336

\section{ON TATYANA GORNSHTEIN'S}

NICOLAI HARTMANN'S PHILOSOHPHY

The Science Publishing House. Leningrad Branch. Leningrad, 1969.

\author{
ANDREI PATKUL \\ $\mathrm{PhD}$ in Philosophy, Senior Lecturer. \\ St Petersburg State University, Institute of Philosophy. \\ 199034 St Petersburg, Russia. \\ E-mail: a.patkul@spbu.ru
}

This article consists in a brief presentation of Tatyana Gornshtein's Nicolai Hartmann's Philosophy (1969) for non-Russian speakers. It provides some information on the author of the work, describes the purpose and structure of the book, and briefly describes the subject matter of each of its chapters. It also focuses on the most interesting points of the author's analysis of Hartmann's philosophy. The different sections of this article follow the order in which the content of the book is presented. Special emphasis is placed on the appraisal and critique of Hartmann's ontology from the perspective of dialectical materialism as elaborated by Gornshtein throughout her book.

Key words: Ontology, Metaphysics, Ontological Factors, Modes of Being, Modalities, Philosophy of Nature, Nicolai Hartmann, Tatyana Gornshtein.

\section{О КНИГЕ ТАТЬЯНЫ ГОРНШТЕЙН} «ФИЛОСОФИЯ НИКОЛАЯ ГАРТМАНА»

Ленинград: Ленинградское отделение издательства «Наука», 1969.

\section{АНДРЕЙ ПАТКУЛЬ}

Кандидат философских наук, старший преподаватель.

Санкт-Петербургский государственный университет, Институт философии.

199034 Санкт-Петербург, Россия.

E-mail: a.patkul@spbu.ru

(C) ANDREI PATKUL, 2019 
Данная публикация является кратким представлением книги Татьяны Горнштейн «Философия Николая Гартмана» (1969) для читателей, не владеющих русским языком. В этой презентации говорится несколько слов об авторе работы, описываются цель и структура книги, раскрывается основное содержание ее глав. Также здесь сделан акцент на наиболее интересные моменты анализа философии Гартмана, проделанного автором книги. Порядок представления содержания книги соответствует порядку глав в данной монографии. Особое внимание уделено оценке и критике гартмановской онтологии с позиций диалектического материализма, которые проводятся Горнштейн на протяжении всей ее книги.

Ключевые слова: Онтология, метафизика, моменты бытия, способы бытия, модальности, философия природы, Николай Гартман, Татьяна Горнштейн.

I would like to give to my foreign colleagues a brief presentation of Tatyana Gornshtein's Nicolai Hartmann's Philosophy, a book, which was written in Russian and published back in 1969. The full title of a work is Nicolai Hartmann's Philosophy. (A Critical Analysis of the Fundamental Problems of Ontology) (Gornshtein, 1969). It was published by The Science Publishing House (Leningrad Branch) as a paperback and numbered 279 pages.

As far as the author of the book, Tatyana Nikolaevna Gornshtein (Russian: Татьяна Николаевна Горнштейн) $(01.29 .1904-09.23 .1980)$ is concerned, she was an expert on history and philosophy of science and a very prominent figure in the intellectual life of the USSR, which is evidenced by the fact that she was the first woman to become a doctor of science (DSc analogue in the USSR and post-Soviet Russia) in philosophy in the Soviet Union ${ }^{1}$, as well as by the fact that it was with her that Ludwig Wittgenstein met in person through the recommendation given by her Moscow colleague, Sofya Yanovskaya, during his visit to Leningrad in $1935^{2}$.

Gornshtein's book includes an introduction, six chapters, a conclusion, a list of Hartmann's works and a list of abbreviations.

The introduction is devoted to Nicolai Hartmann's biography, the date of his birth being somehow mistakenly stated as July 20 (instead of February 20), 1882. It also gives an account on gradual changes in his views. The introduction also includes Gornshtein's outline of the reception which Hartmann's philosophy received, noting,

1 According to E. G. Drukarev: (Drukarev \& Zakhar'yashchev, 2012).

2 Tatyana Gornshtein's daughter, Lyudmila Gornshtein, has published in Russian an account of her mother's meeting with Wittgenstein based on Tatyana Gornshtein's recollections. One of the most striking episodes is associated with Wittgenstein sending Tatyana Gornshtein one of his notebooks, the so-called, 'the yellow notebook'. Later Gornshtein lost it, when she hid it (being afraid of police search) in the Archive of Medical Papers of the city of Vladimir, where she lived and worked at that time. Unfortunately, the memories of Lyudmila Gornshtein are currently available in Russian only (Gornshtein, 2001). 
however, that his philosophy had a more pronounced influence on the so-called 'continental' (especially on German, French and Italian) thinkers and it remained relevant not only for philosophers, but also for natural scientists as well. At the same time, regarding English-speaking philosophy, she states that, "Hartmann is little-known in Anglo-Saxon countries" (Gornshtein, 1969, 4). She explains this situation by the fact that, "due to domination of 'the logical analysis' in England, the continental ontology and metaphysics are generally (not only in Hartmann's vision) ignored as artificial unscientific constructions" (Gornshtein, 1969, 4). Nevertheless, she also makes a brief reconstruction of Hartmann's attitude toward philosophy dominant in the English-speaking world, although without referring to any specific passages in his works, "Hartmann and other metaphysicians, in their turn, consider British empiricism 'philistine', 'destroying the soul' " (Gornshtein, 1969, 4). Besides, in the spirit of the Soviet philosophy, Gornshtein criticizes Hartmann for his alleged political indifference. In fact, according to her, "the mask of non-partisanship and objectivism conceals the reactionary political views of this 'philosopher and hermit"' (Gornshtein, 1969, 5). At first sight it might seem that Gornshtein was forced to accuse Hartmann of political reactionism, attributing 'bourgeois-class nature' to his philosophy, simply because during the Soviet era any author who wanted his work devoted to a philosopher outside dialectical and historical materialism to be published had to criticize this philosopher's thought from the standpoint of these doctrines, and that starting from the very first pages of such work and spicing it with abundant quotations from Marx, Engels and Lenin. However, upon a closer look at Gornshtein's work it becomes clear that she often gives an extensive critique of Hartmann's philosophy from the standpoint of dialectical materialism throughout the entire book. Moreover, the critical conclusions Gornshtein comes to are very logical and seem to be implied by the basic principles of this doctrine. This might incline one to think that this critique was not only accounted for by reasons of pure ideology - rather, it was rooted in Gornshtein's own intellectual standpoint. Therefore, Gornshtein's critique can be of some theoretical importance, valid for understanding Hartmann's legacy, and therefore instead of being ignored, it should be extensively reconstructed.

Gornshtein focuses her work on giving "perhaps, the most complete idea" of Hartmann's philosophy, since the works published abroad addressed only some particular aspects of his thought, but none of the works gave a general overview thereof by the time Gornshtein's book was written. However, she specifies that, given the author's specialization in philosophy, "there is no special consideration of the problems of philosophy of spirit, ethics, aesthetics, as well as of the philosophical problems of biology given in the book" (Gornshtein, 1969, 8). 
The first chapter of the book is titled Ontology and Metaphysics. Herein, Gornshtein presents quite reasonable grounds for Hartmann's distinction between these two philosophical disciplines, as well as reasons for the shift towards ontology which occurred in this philosopher's thought. And yet, she advances that ontology is completely unnecessary from the perspective of dialectical materialism. The same chapter also comprises an analysis of Hartmann's doctrine of the distinction and correlation of ontological factors, explaining the difference between Hartmann's interpretation of this matter and the traditional doctrines of distinction and correlation of essentia and existentia. Gornshtein focuses on the significance which the aporetic way of thinking had for Hartmann, including its potential for understanding ontological and metaphysical problems. In this regard she also gives a historical overview of Hartmann's predecessors in philosophical aporetic, which brings her to analyzing methodological problems of ontology, in their broader sense, as well as methodological problems of Hartmann's research in the history of philosophy.

The second chapter, titled The Doctrine of Spheres of Being, perhaps, belongs to the most informative parts of the book. Gornshtein states that

\begin{abstract}
Hartmann distinguishes four spheres in that totality which is implied by the concept of being, i.e. two primary spheres, independent of human consciousness ('being-in-itself') and two secondary spheres, derivatives ('being-for-us'). The primary spheres have two main modes of being (Seinsweise), i.e. real and ideal being. (Gornshtein, 1969, 35)
\end{abstract}

Two basic modes of being inherent in the primary spheres are "real and ideal being" (Gornshtein, 1969, 35). Gornshtein expands upon the specific content of the concepts of the real and ideal in Hartmann's works, analyzes the distinction between four layers of the real, noting that, according to this thinker, belonging to the time is common to all the real. She considered it to be the reason why Hartmann unjustifiably reckons mental processes and historical events among the real. She believes that the main mistake the philosopher makes resides in treating matter as substance, thus, reducing it to the lower layer of the real, which leads him to being unable to understand that in a broader sense, it is materiality that is the basis of the world's unity. In particular, both psyche and history should be considered as the highest manifestations of the matter, originally capable of self-moving and self-developing (in Gornshtein's view). At the same time, regarding the specifics of the ideal being Gornshtein states that, "The main distinction between the ideal world and the real one is timelessness, unchangeability" (Gornshtein, 1969, 51). It gives her a ground for a rather harsh critique of Hartmann's recognition of the independence of the ideal being, to which the philosopher attributes mathematical objectivity and values. Even though she speaks 
favorably of Hartmann's critique of the subjectivism of positivists and neo-Kantians. The author also states that "Hartmann's doctrine of 'layers' acquired a great influence in foreign philosophy" (Gornshtein, 1969, 44), while emphasizing the distinction between 'layering' and 'gradualness' in its concept. In any event, she opposes Hartmann's doctrine qua dualism to dialectical materialism as a monistic doctrine, being supportive of the latter.

The third chapter of the book is titled The Problem of Cognition. Here Gornshtein notes that Hartmann's doctrine of cognition had been undergoing some important changes in the course of his personal philosophical evolution. She even believes that it is possible to distinguish four evolutional stages this philosopher's doctrine of cognition went through, namely the first one, starting in 1909, the second one, starting in 1921, the third one, starting in 1933, and, finally, the fourth one, characteristic of him, which lasted from 1940 to 1950 . She gives a thorough consideration to the meaning Hartmann assigns to metaphysics of cognition, noting that it does not apply to metaphysics which is built on the basis of the phenomenon of cognition, but gives "a new name to the theory of cognition, which is based not on psychology and logic, but on new critical metaphysics" (Gornshtein, 1969, 75). Gornshtein describes the starting point of metaphysics of cognition posed by German philosopher as the 'agnostic' one. The analysis and estimation of "the law of transcendence of acts of cognition" undertaken by the author of the book come under notice within this chapter. Gornshtein insists that Hartmann suggests a fundamentally new understanding both of transcendental and cognitive attitudes. Hartmann considers the traditional cognitive-theoretic attitude as artificial; however, for him "it is the unity of the cognizing subject and the object in the single real world which is ontologically primary but not the opposition of the subject to the object" (Gornshtein, 1969, 82). It is interesting that within this context Gornshtein compares Hartmann's doctrine of cognition both with Marxist doctrine of cognition and with M. Heidegger's ontological position and his critique of Hartmann, posed in Being and Time (Heidegger, 2001, 208). Other sections of the third chapter of the book are devoted to the analysis of emotional and transcendent acts, a posteriori cognition, the problem of a priori cognition of the real entity, as well as to problems of cognition of the ideal world.

The fourth chapter, the most voluminous in the entire book, is entitled The General Doctrine of Categories. Here Gornshtein says that, starting form 1940, Hartmann begins to conceive ontology as a doctrine of categories. According to her, the analysis of categories, undertaken by the philosopher is much more specific for him than just the formal analysis of the 'factors' and 'modes' of being, which he undertook before. She also highlights the well-known duality in Hartmann's understanding of the cat- 
egories, saying that he "always refers both to principles of being and principles of cognition as categories..." (Gornshtein, 1969, 112). Hartmann considers ontological categories as "the framework of being, its structure" (Gornshtein, 1969, 117). According to Gornshtein, such interpretation of categories initially implies the conviction that the world isn't chaos and it has a stable structure. Hartmann doesn't consider categories to be some ideal entity, for him they have substrate moments. However, "ideal being, as well as the real one, comprises its own ideal categories, its own ideal principles" (Gornshtein, 1969, 121). Still, categories remain neutral in relation to the opposition of idealism / realism. However, proceeding from standpoints of dialectical materialism, Gornshtein identifies Hartmann's doctrine of categories as the doctrine "of objective idealistic nature, similar to the one of the doctrine of ideal being" (Gornshtein, 1969, 125). Further on, this chapter comprises the analysis of the so-called 'fundamental categories', lists the groups such categories are applicable to, presents and interprets Hartmann's table of 'elementary opposites of being.' Gornshtein examines such concepts of Hartmann's philosophy as the structure, the modus, the essence, the attitude, the determination and the dependence. She gives much attention to the analysis of categorical laws established by Hartmann, as well as to the methodological issues of categorical cognition.

The fifth chapter of the book is titled The Problem of Possibility and Actuality (The Modal Analysis of Being). This chapter, perhaps, is the most concise in the entire book. Herein, Gornshtein declare that, "Hartmann seeks to reinforce his idealistic ontology with the analysis of 'modalities of being', id est the actuality, the possibility, the necessity and the contingency" (Gornshtein, 1969, 184). She notes that, according to Hartmann, all previous experiments of ontology of modalities were contradictory due to the insufficient differentiation of the ideal and real ways of being. Hereafter, her analysis of Hartmann's doctrine of modalities addresses the modalities of real being and ideal being. The most interesting here is the analysis of differences between real and ideal possibilities, as well as that of differences in the correlation of the possibility and the actuality in real and ideal being. Eventually, Gornshtein gives an ambivalent account of Hartmann's theory of modalities. On the one hand, according to her, it is 'flawed', particularly with regard to the doctrine of the possibility and the actuality, which is caused by the 'objective idealistic' and 'generally metaphysical' nature of Hartmann's philosophy. On the other hand, she speaks highly of Hartmann applying 'the historical approach' to the doctrine of modalities, "substantiated by an extraordinary erudition in the field of the history of philosophy" (Gornshtein, 1969, 202).

Finally, there is the last, sixth chapter, titled The Certain Problems of Philosophy of Nature. Gornshtein starts it by noting that there is an opposition between philos- 
ophy of science, in particular, natural science and philosophy of nature in modern philosophy. She believes that it is more common to Soviet philosophical literature to appeal to philosophy of science, which in turn is understood as "the positivistic methodology of natural science", but Nicolai Hartmann's natural philosophy was never analyzed by Soviet philosophers. Hereafter, she reconstructs four periods of history of natural philosophy, distinguished by Hartmann, noting that, according to him, "there has been nothing that could be considered as a genuine philosophy of nature for the last hundred years (1850-1950)..." (Gornshtein, 1969, 205). The description of the correlation between natural philosophy and metaphysics posed by Hartmann, as well as that between natural philosophy and natural science, given by Gornshtein is also of some interest. She reconstructs three classes of categories of natural being posed by Hartmann, namely (1) dimensional categories, (2) cosmological categories, (3) organological categories. Analyzing dimensional categories, Gornshtein focuses on the distinction between concepts of the ideal and real spaces as well as of the so-called perceptual space given by Hartmann. It is precisely the interpretation of the latter which makes her state that, "Hartmann was strongly influenced by Kant's apriorism, despite a different version of a concept of a priori cognition" (Gornshtein, $1969,215)$. In the section Hartmann devoted to time, Gornshtein also distinguishes the real time, the ideal time and the time of intuition. Hartmann's understanding of the essence of the 'now' moment is crucially important to her. Interestingly, she compares, albeit briefly, Hartmann's ideas of time to the ideas of the same matter which belonged to such English-speaking philosophers as G. Witrow, B. Russell, A. Whitehead. Hereafter, she addresses Hartmann's appraisal of the relativity theory. The quintessence of the section on cosmological categories is represented by Gornshtein's analysis of Hartmann's concept of causality, with particular attention paid to Hartmann's critique of positivism identifying "laws governing phenomena with causality", and with comparison made between his ideas of causality and those of J.P.Sartre. She also refers to some research made by some prominent Soviet philosophers on the problem of causality. However, Gornshtein argues that, "the struggle with teleology is a progressive point of Hartmann's natural philosophy..." (Gornshtein, 1969, 255), yet “...Hartmann, defending the principle of determinism, does not go beyond the mechanistic one-line understanding of causality in the physical world, denies objective contingency" (Gornshtein, 1969, 255). Interestingly, the last chapter contains a noteworthy analysis of the concept of a dynamic system and the relation between dynamical systems and the gradual character of nature. However, estimating Hartmann's philosophy of nature, as a whole, Gornshtein believes that "Hartmann is intent on proving the limitation of scientific cognition as such" (Gorn- 
shtein, 1969, 266). She believes that his idea of natural philosophy was trapped by agnosticism.

Tatyana Gornshtein devotes the conclusion of the book to the summary of the key ideas. She insists on Hartmann's philosophy being of the objective idealistic nature, although, according to her, the doctrine advanced by him cannot be considered 'uniform' in this regard, since some of the aspects of his doctrine can be identified as subjective-idealistic, positivistic and also materialistic (especially in regard to natural philosophy). However, she considers the insistence on the similarity between Hartmann's philosophy and dialectical materialism 'illusory'. Gornshtein goes into details and presents her critique of some arguments which justify the similarity of Hartmann's ontology to dialectical materialism, showing, for instance, that Günter Jacobi's philosophy, which owes a lot to Hartmann's ontology, leads to theological conclusions. Moreover, according to her, in respect of methodology, "transformation of Hegel's dialectic undertaken by Hartmann is much closer to Neo-Hegelianism than to Marxism" (Gornshtein, 1969, 270). Generally, Gornshtein believes that in criticizing positions of Neo-Kantianism and positivism, Hartmann still turns out to be dependent on them. Therefore, according to her, eventually, "Hartmann's eclectic philosophy is epigone" (Gornshtein, 1969, 273).

Concluding this presentation of Nicolai Hartmann's Philosophy by Tatyana Gornshtein, I would like to point out that, despite its touch of tendentiousness, especially noticeable at some points, it still remains a highly competent presentation of the German philosopher's ideas, demonstrating a surprisingly deep insight into his works, and it gives quite a noteworthy appraisal and critique of his ontology from the standpoint of dialectical materialism. Therefore, it remains relevant for Hartmann studies. Needless to say, it was one of few rare sources, from which Soviet intellectuals could get information on Nicolai Hartmann's ideas, and it still remains a most important document for studying both the history of the reception Hartmann's philosophy in the Russian-speaking community and the history of Soviet philosophy in general. Perhaps, it is worth noting that Gornshtein's work was employed in philosophical didactics not only for courses on history of modern philosophy, but also for systematic courses on general ontology at Saint Petersburg State University during the Perestroika era and also for at least one decade of post-Soviet times in Russia. Finally, I would like to express my sincere hope that eventually, after all copyright issues will have been settled, Tatyana Gornshtein's Nicolai Hartmann's Philosophy will be translated into English (and, perhaps, into other foreign languages) and become a part of the common heritage of the world Hartmann studies. 


\section{REFERENCES}

Drukarev, E. G., \& Zakhar'yashchev, V.(2012). Pis'ma v redaktsiyu [Letters to Editorial Staff]. Zvezda, 10. Retrieved from http://www.zh-zal.ru/zvezda/2012/10/p24-pr.html. (in Russian).

Gornshtein, T.N.(1969). Filosofiya Nikolaya Gartmana (Kriticheskii analiz osnovnykh problem ontologii) [Nicolai Hartmann's Philosophy (The Critical Analysis of the Fundamental Problems of Ontology)]. Leningrad: Nauka. (in Russian).

Gornshtein, L.Z.(2001). Lyudvig Vitgenshtein v Leningrade [Ludwig Wittgenstein in Leningrad]. Obshchestvennye nauki i sovremennost' [Social Sciences and Modernity], 2. Retrieved from http:// ecsocman.hse.ru/data/800/991/1231/018gORNx5bTEJN.pdf. (in Russian).

Heidegger, M. (2001). Sein und Zeit. Tübingen: Max Niemeyer Verlag. 